\title{
Financing of Agricultural Enterprises by Microfinance Banks in Orlu Agricultural Zone of Imo State, Southeast Nigeria
}

\author{
F. O. Nwosu, B. O. Ibeagwa, H. U. Anene, K. H. Anyiam, and G. I. Isaiah
}

\begin{abstract}
This study was conducted to identify and investigate the problems and constraints encountered by Agricultural enterprises owners (i.e., loan beneficiaries) in obtaining loan from microfinance Banks in Orlu Agricultural zone in Imo State, Nigeria. A representative sample was selected through multistage sampling technique. Data were collected through the use of structured questionnaire and analyzed using descriptive statistics. A total of sixty (60) Agricultural enterprises owners who obtained loan from microfinance banks were selected for the study. The results of data analyzed showed that majority of the loan beneficiates are married, fairly experienced, illiterate, have small farm size, used family labour in their farm enterprises, middle-aged, operated at subsistence level of production and obtained loan between $(\mathrm{N} 10,000-\mathrm{N}$ 200,000). Further analysis revealed that high interest rate was one of the most pressing problem that the agricultural enterprises owners encountered in obtaining loan from microfinance banks in the area. It was recommended that less burdensome administrative procedures, review of interest rates charged on loan requested, increase in sensitization activities by stakeholders in the Agricultural sector, more effective screening, follow-up operations and mentioning operation as well as launching an initiative tagged "loan plus" specially coordinated to solve these problems and constraints of the loan beneficiaries in the area.
\end{abstract}

Key words - Farm enterprises, Imo State, loan beneficiaries, microfinance banks, Nigeria, production.

\section{INTRODUCTION}

Farm credit is widely recognized as the intermediating factors between adoptions of farm technologies and increased farm income among agricultural enterprises populace in Imo state and Nigeria in general. This is because it serves as a fundamental catalyst to encourage sustainable agricultural productivity [1]. Credit refers to the faith placed by a lender (creditor) in a borrower (debtor) by extending loan, usually in form of money, goods, inputs, and securities to debtors [2], [3].

The aim of establishing microfinance banks by Central Bank of Nigeria is to make financial services especially credit, accessible to the resource-poor but active farmers or agricultural enterprises owners. This is because of inability of formal banks to include these set of resource-poor but active entrepreneurs in financial services [4]. Microfinance banks

Published on September 08, 2021.

F. O. Nwosu, Department of Agricultural Economics, Federal University of Technology, Owerri, Nigeria.

(e-mail: fidelis.nwosu@futo.edu.ng)

B. O. Ibeagwa, Department of Agricultural Economics, Federal University of Technology, Owerri, Nigeria. differ from formal banks in various respects. These include absence of collateral, simplicity of operations: institutional role to connect the poor and underprivileged of the society in developing countries [5].

In Nigeria, financing of agricultural enterprise is very important because of its positive impact in productivity growth and expansion of the business enterprise [6]. Also, the importance of Agricultural sector to the national development cannot be overemphasized [7]. Central Bank of Nigeria $(\mathrm{CBN})$ as the apex regulatory bank has been performing several roles and actions so as to ensure availability of agricultural credit to farmers and other agricultural enterprises owners. This was achieved by creating an enabling financial environment for disbursement of loan facilities to micro, small and medium scale enterprise [8].

Despite the money pumped into the microfinance banks by the Central bank of Nigeria $(\mathrm{CBN})$, the agricultural micro, small and medium scale enterprise still complain of lack of funds to growth and expand the production and productivity of their agricultural enterprise. This has consequently created a gap in knowledge. It is this gap in knowledge that this study strives to address. Therefore, this study is designed specifically to:

i. Examine the socio-economic characteristics of the loan beneficiaries of microfinance banks in study area.

ii. Identify the problems and constraints these loan beneficiaries of agricultural enterprises encountered in obtaining loan from microfinance banks in the area of study.

\section{Methodology}

The study was conducted in Orlu Agricultural zone of Imo State, Nigeria. The zone is located in tropical rainforest belt of Nigeria. A total number of eleven (11) Local Government Areas (L.G.As) make up the Orlu Agricultural zone. The L.G.As are Njaba, Ideato south, Ideato North, Isu, Nwangele, Nkwere, Oru East, Oru West, Orsu, Oheji/Egbema and Ogutu.

A representative sample was selected using multi-stage sampling technique. The first stage comprised the selection of three (3) local government areas (L.G.As) from the zone. These L.G.As are Njaba, Orlu and Nwangele. The reason for this selection is because of the high number of microfinance

H. U. Anene, Department of Agricultural Economics, Federal University of Technology, Owerri, Nigeria.

K. H. Anyiam, Department of Agricultural Economics, Federal University of Technology, Owerri, Nigeria.

G. I. Isaiah, Department of Agricultural Economics, Federal University of Technology, Owerri, Nigeria. 
banks in those areas. In the second stage, one (1) microfinance banks was selected from each of these selected local government area (L.G.As) making a total number of three (3) microfinance banks purposively selected for this study. The third stage comprised the selection of twenty (20) from each of the selected microfinance banks, making a list of sixty (60) loan beneficiaries, using simple random sampling. The list of loan beneficiaries was supplied by the block extension agents in the selected L.G.As.

Data were obtained from primary and secondary sources. A set of structured questionnaires were used to elicit data from the loan beneficiaries. Data collected were analyzed using frequency counts, percentages and mean values represented in tabular from. This was used to analyze objective 1 and 2 .

\section{RESUlTS AND DisCUSSION}

\section{A. Socio-Economic Characteristics of Respondents}

TABLE I: THE SOCIO-ECONOMIC CHARACTERISTICS OF LOAN BENEFICIARIES ( $\mathrm{N}=60)$

\begin{tabular}{|c|c|c|c|}
\hline \multicolumn{2}{|c|}{ Socio-economic Characteristics } & \multirow{2}{*}{$\begin{array}{l}\text { Frequency } \\
3\end{array}$} & \multirow{2}{*}{$\begin{array}{c}\text { Percentage } \\
5.0\end{array}$} \\
\hline Age & $21-30$ & & \\
\hline & $31-40$ & 10 & 16.7 \\
\hline & $41-50$ & 26 & 43.3 \\
\hline & $51-60$ & 21 & 35.0 \\
\hline \multicolumn{4}{|c|}{ Mean $=47$ years } \\
\hline \multirow[t]{2}{*}{$\operatorname{Sex}$} & Male & 26 & 43.3 \\
\hline & Female & 34 & 56.7 \\
\hline \multirow[t]{2}{*}{ Marital status } & Single & 5 & 8.3 \\
\hline & Married & 55 & 91.7 \\
\hline \multirow{4}{*}{$\begin{array}{c}\text { Education } \\
\text { Attainment } \\
\text { (years spent } \\
\text { in school) }\end{array}$} & 0 & 17 & 28.3 \\
\hline & $1-6$ & 21 & 35.0 \\
\hline & $7-12$ & 21 & 35.0 \\
\hline & $13-18$ & 1 & 1.7 \\
\hline \multirow{5}{*}{$\begin{array}{c}\text { Household } \\
\text { Size (number } \\
\text { of persons) }\end{array}$} & $0-3$ & 9 & 150 \\
\hline & $4-6$ & 32 & 53. \\
\hline & $7-9$ & 18 & 30.0 \\
\hline & $10-12$ & 1 & 1.7 \\
\hline & Mean $=6$ persons & & \\
\hline \multirow{5}{*}{$\begin{array}{c}\text { Farm size (in } \\
\text { hectares) }\end{array}$} & $0.1-2.0$ & 32 & 53.3 \\
\hline & $2.1-4.0$ & 13 & 21.7 \\
\hline & 4.1-6.0 & 2 & 3.3 \\
\hline & $6.1-8.0$ & 3 & 5.0 \\
\hline & $\begin{array}{c}\text { Mean }=2.25 \\
\text { hectares }\end{array}$ & & \\
\hline \multirow{5}{*}{$\begin{array}{c}\text { Farming } \\
\text { experience (in } \\
\text { years) }\end{array}$} & $1-8$ & 22 & 36.7 \\
\hline & $9-16$ & 30 & 30.0 \\
\hline & $17-24$ & 7 & 11.7 \\
\hline & $25-32$ & 1 & 1.6 \\
\hline & Mean $=10.7$ years & & \\
\hline \multirow{3}{*}{$\begin{array}{l}\text { Types of farm } \\
\text { enterprises }\end{array}$} & Crop farming & 32 & 53.3 \\
\hline & Livestock farming & 16 & 26.7 \\
\hline & $\begin{array}{c}\text { Both crop and } \\
\text { livestock enterprise }\end{array}$ & 12 & 20.0 \\
\hline \multirow{3}{*}{$\begin{array}{c}\text { Types of } \\
\text { labour (used } \\
\text { in the farm } \\
\text { enterprise) }\end{array}$} & Family labour & 28 & 46.7 \\
\hline & Hired & 20 & 33.3 \\
\hline & $\begin{array}{c}\text { Both family and } \\
\text { hired labour }\end{array}$ & 12 & 20.0 \\
\hline \multirow{2}{*}{$\begin{array}{c}\text { Level of } \\
\text { production (in } \\
\text { farm } \\
\text { enterprises) }\end{array}$} & $\begin{array}{c}\text { Mechanized/ } \\
\text { commercial }\end{array}$ & 8 & 8.0 \\
\hline & $\begin{array}{c}\text { Subsistence } \\
\text { farming }\end{array}$ & 52 & 92.0 \\
\hline \multirow{3}{*}{$\begin{array}{c}\text { Loan } \\
\text { obtained (in } \\
\text { naira) }\end{array}$} & $10,000-200,000$ & 41 & 68.3 \\
\hline & $201,000-400,000$ & 10 & 16.7 \\
\hline & $401,000-600,000$ & 9 & 14.0 \\
\hline
\end{tabular}

Source: field survey, 2017.
TABLE II: FREQUENCY DISTRIBUTION OF LOAN BENEFICIARIES BASED ON THE PROBLEMS \& CONSTRAINTS

\begin{tabular}{lcc}
\hline \hline $\begin{array}{c}\text { Identified problems } \\
\text { and constraints }\end{array}$ & Frequency & Percentage \\
\hline \hline $\begin{array}{c}\text { Poor service delivery } \\
\text { Burdensome } \\
\text { administrative } \\
\text { procedures } \\
\begin{array}{l}\text { Delay in loan } \\
\text { disbursement }\end{array}\end{array}$ & 2 & 1.67 \\
$\begin{array}{l}\text { Inadequate loan } \\
\text { disbursement } \\
\text { Insufficient loan } \\
\text { management }\end{array}$ & 23 & 9.17 \\
$\quad \begin{array}{l}\text { Refusal to loan } \\
\text { applied because of } \\
\text { Lack of collateral } \\
\text { High interest rate }\end{array}$ & 29 & 19.17 \\
\hline \hline $\begin{array}{l}\text { Source: field survey, 2017. } \\
\text { N/B: multiple responses were recorded. }\end{array}$ & 24.17 \\
\hline
\end{tabular}

Table I showed that the mean age of the loan beneficiaries fell within the productive age of 47 years. This indicates that the loan beneficiaries were middle aged persons who are still physically active, vibrant, dynamic and are more likely to adopt innovations better and faster than their older counterparts [9]. The results show that majority $(56.7 \%)$ of the loan beneficiaries were females. This is an indication that worsens are energetic, strong, and hardworking and therefore expected to do much better if they are given better access to credit facilities from microfinance banks [10]. The table further shows that $91.7 \%$ of the loan beneficiaries are married. This result also supports the idea that married people have more responsibilities hence their increased need for coping strategies to financial security obligations in their households [11]. The results also showed that about $22 \%$ of the loan beneficiaries have merely attained secondary and tertiary education level. This is an indication that the loan beneficiaries are predominantly uneducated. This is also indicating the fact that majority of the loan beneficiaries will not properly appreciate the importance of obtaining loan from microfinance banks for growing their individual productive capacities because of their poor level of education. This is consistent with the findings of [12] that education is an investment in human capital which able to narrow his information gaps and achieves more productive performance. The mean household size was 6 persons, which implies that of the loan beneficiaries spent a modest amount on feeding, clothing, hospital bill etc. hence by implication; they have a reasonable farm labour that could help in their enterprises [13]. The table further revealed that the loan beneficiaries have a mean farm size of 2.25 hectares, majority of the loan beneficiaries are engaged in crop farming and their farm enterprises are merely operated at the subsistence level. These points to the fact that the loan beneficiaries are predominantly poor and there is a great need for more access to credit facilities from microfinance banks. This is in agreement to findings of [5] where he stated that microfinance banks should be properly funded and managed so as to live up to its unique and statutory function of timely and adequate provision of access to financial services to the productive but poor farms. This will serve the purpose of productivity growth, initiate wealth creation and drastic reduction of poverty. 
From Table II, over $85 \%$ of the loan beneficiaries mentioned high interest rate, $51.67 \%$ mentioned lack of collateral, $24.17 \%$ mentioned inadequate disbursement of loan applied, and $30 \%$ of the loan beneficiaries mentioned insufficient management of loan obtained from microfinance banks, $19.17 \%$ mentioned delay in disbursement of loan applied, 9.17\% mentioned burdensome administrative procedures and 1.67 mentioned poor services delivery by the microfinance banks. If the number of persons who mentioned each problem is used as a measure of its importance, this implies that high interest rates, among others is the most pressing problem of the loan beneficiaries. This result is consistent with the findings of [5] that high interest rates constitute serious challenge to the prospective loan beneficiaries in obtaining microfinance banks loan.

\section{CONCLUSION}

The study examined the socio-economic characteristics of the loan beneficiaries and identified problems and constraints which hinders the loan beneficiaries from obtaining loan from microfinance banks in the area. It can be concluded that majority of the loan beneficiaries are married, middle-aged, and illiterate, fairly experienced, have small farm size, uses family labour in their farm enterprise, are engaged in crop farming and are producing at subsistence level. The study also revealed that high interest rate was one of the most pressing problems that the loan beneficiaries encountered in obtaining loans from microfinance banks. Other problems identified in the study includes poor service delivery, denial of loan applied because of lack of collateral, inadequate amount of loan disbursed, insufficient management of loan obtained, delay in disbursement of loan applied and unfriendly administrative procedures.

\section{RECOMMENDATION}

In the light of the findings of this study, it is recommended that :

i. Downward review of the official interest rates and reform of microfinance banks so as to make them more sensitive to the peculiar needs and profile of the loan beneficiaries.

ii. Microfinance banks should intensify their loan screening, monitoring and follow-up exercise so as to checkmate irregularities such as loan Diversion, improper management of loan obtained, fraudulent practices and other improper behavior that may be exhibited by prospective loan beneficiaries.

iii) More sensitization efforts should be conducted so as the assist the farmers in the area so they can be sufficiently educated on the important need to obtain credit to grow their farm business enterprises.

iv) Government, through the assistance of various stakeholders and other extension services should launch an initiative tagged "loan easy" this initiative should be well coordinated by thorough and time tested experts in the industry and should be specially tailored to help the ruralpoor enterprise owners to overcome their present productive and economic status. v) There should be less burdensome administrative procedures in obtaining loan in order to encourage more farmers to gain access to loan facility from microfinance banks.

\section{REFERENCES}

[1] M. A. Akudugu, "Estimation of the determinants of credit demand by farmers and supply by rural banks in Ghana upper East region," Asian journal of agriculture and rural development, 2(2): 189-200, 2012.

[2] B. T. Omonona, A. T. Akinterinwa, Y. A. Woyinka, "Credit constraint and output supply of Cowan farmers in Oyo State Nigeria," European Journal of Social Sciences, 6 (3): 382-390, 2008.

[3] S. B. Akpan, V. P. Inimfon, J. U. Samuel, A. O. Edem, E. O. Uwenedimo, "Determinants of credit Access and demand among poultry farmers in Akwa Ibom State," Nigeria. American Journal of experimental Agriculture, 3(2): 293-307, 2013.

[4] O. O. Kuye, "Determinants of loan default and repayment rates by cassava farmers in south-south Nigeria," A case study of bank of agriculture and first bank of Nigeria, European Journal of agriculture and forestry research, 3(4): 48-57, 2015.

[5] C. Kanu, "Microfinance Banks Operations in Nigeria, constraints and suggested solutions: An evaluation. Global journal of contemporary research in accounting," Auditing and business ethics. An online international research journal, 1(2), 2015.

[6] I. O. Oshaji, A. Henri-Ukoha, U. A. Essien; O. B. Ibeagwa, I. J. Uhuegbulem, I. O. Ejike, "Productivity of Enterprises owned by Women Loan beneficiaries and non loan beneficiaries in Imo State, Nigeria: A comparative Analysis," International Journal of Small business and Entrepreneurship Research, 4(1): 2016.

[7] M. A. Olaitan M.A "Emerging issues on micro and rural financing in Nigeria," A publication of the central bank of Nigeria. 35(1): 64-71, 2001.

[8] C.B.N, "Guideline and procedures for the establishment of microfinance banks in Nigeria" presented by CBN, Abuja, Nigeria, 2008.

[9] D. O. Ohajianya, J. A. Echetama, P. O. Offodile, C. O. Oguagwu, A. Henri-ukoha, E. Okereke, N. O. Anyaoha, "Altercative efficiency among maize farmers in Imo State," Nigeria. Report and opinion, 2 (12):139-147, 2010.

[10] H. A. Ajagbe, "Demand for Institutional Credit by Small scale farmerss I Nsukka Local Government Area of Enugu State, Nigeria," A Post Graduate Seminar Paper presented to Department of Agricultural Economics, University of Nigeria Nsukka, 2012.

[11] O. T. Ikwuakam, "Determinants of social economic status of cassava processing entrepreneurs in South-eastern Nigeria," Journal of agriculture and veterinary sciences, 5(2): 140-150, 2013.

[12] J. S. Orebiyi, "The performance of rural credit markets in Imo State," Nigeria, 2000.

[13] A. Henri-Ukoha, C. Chiezie, M. N. Osuji, I.I Ukoha, "Rate of information and communication Technology (ICT) use: its determinants among livestock farmers in Ukwa West L.G.A, Abia State, Nigeria," International Journal of Agricultural and food sciences 2012, 2(2): 51-54. Universal Research Publication, 2012.

[14] Unpublished Ph.D thesis. Federal University of Technology, Owerri. 